\title{
Dönüşümcü ve Etkileşimci Liderlik Algısının Yenilik Performansı Algısına Etkisi: Konaklama işletmeleri Örneği
}

\author{
RIfat Iraz ${ }^{1}$ (iD) Mehmet Ali Canbolat ${ }^{2 * *}$ (iD \\ ${ }^{1}$ Selçuk Üniversitesi, Iktisadi ve Idari Bilimler Fakültesi, Konya, Türkiye, rifat@selcuk.edu.tr, ORCID: 0000-0002-2774-8428 \\ ${ }^{2}$ Karamanoğlu Mehmetbey Üniversitesi, Sosyal Bilimler Meslek Yüksekokulu, Karaman, Türkiye, malican70@gmail.com, ORCID:0000-0003-1235-9013
}

Öz

Karaman il genelinde faaliyet gösteren konaklama işletmelerinde çalışan personelin dönüşümcü ve etkileşimci liderlik algılarının yenilik performansı algılarına etkisinin belirlenmesi amacıyla kesitsel tipte planlanan bu araştırma toplam 82 kişi ile yürütülmüştür. Araştırma nicel araştırma desenindedir. Araştırmada veri toplama formu olarak demografik bilgileri içeren 6 soru, dönüşümcü liderlik ölçeği (20 madde), etkileşimci liderlik ölçeği (16 madde) ve yenilik performansı ölçeği (5 madde) uygulanmıştır. Veriler frekans, açıklayıcı faktör analizi, doğrulayııı faktör analizi, korelasyon analizi ve çoklu regresyon analizlerine tabi tutulmuştur. Sonuç olarak dönüşümcü liderlik ve yenilik performansı algıları arasında pozitif yönde bir ilişkiye rastlanırken etkileșimci liderlik algısı ile yenilik performansı algısı arasında herhangi bir ilişkiye rastlanılmamıstır. Buradan hareketle konaklama işletmelerinde dönüşümcü liderlik tipinde yöneticilerin istihdamına ağırlık verilmesi gerektiği önerilebilir.

Anahtar Kelimeler: Dönüşümcü Liderlik, Etkileşimci Liderlik, Yenilik Performansı, Konaklama İşletmeleri

\section{The Effect of Transformational and Transactional Leadership Perception on Innovation Performance: The Case of The Accommodation Companies}

\begin{abstract}
This cross-sectional study was conducted with a total of 82 people who were working in the accommodation establishments in the province of Karaman. The aim of the study is to investigate the effect of the transformational and transactional leadership perception on the perception of the innovation performance. This study is a kind of quantitative research design. In the research, 6 questions for demographic information, transformational leadership scale (20 items), transactional leadership scale (16 items) and innovation performance scale (5 items) were performed as data collection form. Frequency, explanatory factor analysis, confirmatory factor analysis, correlation analysis and multiple regression analysis were applied to the data obtained. As a result, while a positive relationship was found between the perception of transformational leadership and innovation performance, no relationship was found between the perception of transactional leadership and the perception of innovation performance. From this point of view, it can be suggested to hire mainly the transformational leadership type managers in the accommodation enterprises.
\end{abstract}

Keywords: Transformational Leadership, Transactional Leadership, Innovation Performance, Hospitality Businesses
Cilt 5, Sayı 2, 2021

ss. $327-345$

Gönderim : 05.05.2021

1. Düzeltme: 20.06 .2021

Kabul Tarihi: 09.07.2021

\section{Research Article}

Vol 5, No 2, 2021

pp. 327-345

Received : 05.05.2021

Revision1: 20.06 .2021

Accepted: 09.07.2021

\section{Önerilen Atıf/Suggested Citation}

Iraz, R. ve Canbolat, M. A. (2021). Dönüşümcü ve Etkileşimci Liderlik Algısının Yenilik Performansı Algısına Etkisi: Konaklama İşletmeleri Örneği. Güncel Turizm Araştırmaları Dergisi, 5(2), 327-345.

**Sorumlu yazar e-posta: malican70@gmail.com 


\section{GİRIŞ}

İnsanlar sosyal varlıklar olup çeşitli nedenlerle geçici yer değişikliği yapmakta ve bu sayede turizmin olmazsa olmaz bir parçası haline gelmektedirler. Gerek iş yaşantısının ürettiği stres faktörü gerekse sosyal varlık olmanın getirdiği sosyalleşme ya da tatil ihtiyacı bireyleri turistik faaliyetlere yöneltmektedir. Bu faaliyetler ise genellikle otel, tatil kötü, pansiyon vb. gibi konaklama işletmelerinde gerçekleştirilmektedir. Bu işletmelerdeki konaklama deneyimleri ise müşterinin iş/arkadaş çevresi, sosyal medya ya da online rezervasyonu gerçekleştiren platformun yorum bölümlerinde paylaşılabilmektedir. Bu yorumların şekillenmesinde ise yenilikçi teknoloji ya da uygulamaların varlığı baz alınabilmektedir.

Konaklama işletmelerinde yeniliğin temel taşlarından olan güncel teknolojilerin kullanımı yüksek altyapı maliyetlerinden ötürü şirket yönetimlerinin üzerinde hassasiyet gösterdiği konulardan bir tanesi olarak karşımıza çıkmaktadır. Ayrıca konaklama işletmeleri yöneticileri, misafirlerin konaklama deneyimlerini değerlendirmelerine önem vermektedirler. Ancak yöneticiler başta kar odaklı hareket edebildiklerinden yeni yatırımların ilerleyen dönemlere aktarılmasını da tercih edebilmektedirler. Bu noktada yöneticilerin liderlik özellikleri ön plana çıkmaktadır.

Temel olarak bir yöneticinin başkalarına yol göstermek için kullandığı güç şeklinin, onun liderlik türünü belirlediği söylenebilir (Kinter, 2016). Modern liderlik yaklaşımları her geçen gün yeni liderlik modellerine yenilerini eklemekte ve örgüt başarısına etki eden liderlik tiplerini ortaya koymaya çalışmaktadır. Birçok modern liderlik türünden iki tanesi ise dönüşümcü (transformational) ve etkileşimci (transactional) liderlik tipleridir. Dönüşümcü liderler yeniliğe daha yatkınken etkileşimci liderlerin daha gelenekselci olduğu bilinmektedir (Kanungo, 2009).

$\mathrm{Bu}$ bakış açısı ile araştırmanın amacı, konaklama işletmelerindeki çalışanların dönüştürücü ve etkileşimci liderlik algılarının yenilik performansı algısına olası etkisini ortaya koyabilmektir. Literatür incelendiğinde belirlenen değişkenlerle ilgili münferit çalışmalar (Zeng, Xie ve Tam, 2010; İraz, Abul ve Kurnaz, 2017; Cıranoğlu, 2020; Çağlıyan, Attar ve Külahll, 2021) bulunsa da tüm bu değişkenlerin birlikte kullanıldığı bir araştırmaya rastlanılmamıştır.

Konaklama işletmeleri için yenilik olmazsa olmaz unsurlardan bir tanesidir. Buna bağlı olarak oluşturulan yeniliklerin ölçümlenebilmesi adına yenilik performansından yararlanılabilir. Konaklama işletmelerinde yeniliğe karar veren kişiler ise işletme yöneticileri, diğer bir ifade ile liderlerdir. Özellikle liderlik özellikleri ile yenilik performansını konaklama işletmelerinde inceleyen bir araştırma ile karşılaşılmaması bu araştırmanın temel problemine dayanak oluşturmuştur. Bu durum ise araştırmanın özgün değerini ortaya koymaktadır. Bu doğrultuda öncelikle temel kavramlara ve literatüre değinilmiş daha sonra araştırmanın yöntemi hakkında bilgiler verilerek veri analizlerine geçilmiştir. Son olarak analiz sonucunda elde edilen bulgular 1şı̆̆ında sonuçlar derlenerek önerilerde bulunulmuştur. 


\section{Kavramsal Çerçeve}

Dönüşümcü (dönüşümsel/dönüştürücü) liderler, çalışanlarını lider olma konusunda etkileyebilen, onları cesaretlendiren, statü farkı gözetmeksizin fikirlerini ciddiye alan, karizma ve esin kaynağı olmayı bütünleştirerek izleyicilerinin hayranlık duyabileceği bir rol modeldirler (İşcan, 2006). Dönüşümcü liderler, astlarına telkinle güdüleme veren, entelektüel uyarım sağlayan ve onlarda enerji oluşturan liderlerdir (Karip, 1998). Ayrıca emir vermek yerine astlarını teşvik eder, motive eder ve heyecanlandırırlar (Lee, 2014). Çalışanlar arasındaki farklılıkları göz önünde bulundurarak büyümek ve gelişmek için yardıma ihtiyaç duyanlara mentor olarak davranırlar (Bass, 1990). Başkalarını aslen amaçladıklarından daha fazlasını yapmaya ve hatta mümkün olabildiğince daha da fazlasını yapmaya motive ederler (Bass ve Riggio, 2008). Temel olarak astlarının arzularını, değerlerini, düşünce ve davranışlarını etkilerler (Zhu, Sosik, Riggio ve Yang, 2012). Bütün bunların yanında takım motivasyonunun gelişimini kolaylaştıran bir katalizör görevi de görmektedirler (Wang, Kim ve Lee, 2016). Nihayetinde dönüşümcü liderlik, karmaşık bir yapıya sahip olan örgütsel ortamlarda çalışmakta olan ve karşılıklı olarak birbirine bağımlı bireyler arasındaki etkileşimli bir ilişkinin sonucudur (Whittington, Goodwin ve Murray, 2004).

Lider ile çalışanlar arasındaki ilişkinin anlaşma ile sağlandığı (Bakan, Erşahan, Büyükbeşe, Doğan ve Kefe, 2015) etkileşimci (etkileşimsel) liderlik ise örgütün daha önce tanımlanan amaçlarına ulaşmak için çalışanların nasıl yönlendirilmesi gerektiği ile ilgilenir (Sobacı, 2014). Etkileşimci lider, örgütün iş standartlarına ulaşıldığı, görev odaklı çalışılan ve astların kendilerine verilen görevlerini başarıyla yerine getirmeleri sonucunda ödüllendirildiği, tersi durumda ise cezalandırıldıkları bir yönetim anlayışına sahiptir (Kinter, 2016). Diğer bir ifade ile çalışanları koşullu olarak ödüllendirseler de belirlenen hedeflere ulaşılamadığı takdirde bir takım yaptırımlar uygulayacaklardır (Dönmez, 2014). Etkileşimci liderler, eski yaklaşım ve geleneklere daha çok bağlı kalmakla birlikte geleceğe dönük herhangi bir vizyon yaklaşımı geliştirmeyi düşünmezler (Ersoydan, 2014). Bir taraftan yenilik ve risk alma olgularından kaçınırlarken diğer taraftan yüksek çıktılara ulaşmayı amaçlamaktadirlar (McMurray, Islam, Sarros ve Pirola-Merlo, 2012).

Etkileşimci liderlik davranışı; koşullu ödüllendirme, aktif istisnalarla yönetim, pasif istisnalarla yönetim ve serbest bırakıcı liderlik alt boyutlarından oluşurken dönüşümcü liderlik davranışı; ideal etki ve karizma, ilham verici liderlik, zihinsel teşvik ve bireysel ilgi alt boyutlarından oluşmaktadır (Yavuz, 2008). Etkileşimci liderler geleneklere, alışılagelmiş kurallara bağlı ve yeniliğe kapalı bir özellik gösterirken, dönüşümcü liderler bu durumun zıttı yönünde -kuralların yenilenmesi hususunda çaba gösterilmesi gibi- bir özellik gösterirler (Temel, 2016). Her iki liderlik tipi de özellikle 90'lardan sonra sıkça araştırma konusu olmaya başlamıştır (Conger, 1999).

Bir diğer değişken olan yenilik performansı kavramını açıklamadan önce yeni ve yenilik (inovasyon) kavramlarını açıklamakta yarar vardır. Yeni, alışılmamış olanın 
fark edilmesidir. Yenilik ise bir ürün ya da hizmetin pazarda ilk defa tanınması ya da ilk defa yeni bir ürün ya da hizmet ortaya çıkarma ve keşif süreci şeklinde tanımlanabilmektedir (Oğuztürk, 2003). Bu kavram ilk olarak 1939 yılında Joseph Schumber tarafından ele alınmıştır (Balkı, İlhan ve Özkoç, 2020). Yenilikler, işletmelerin orta ve uzun dönemli başarıları için büyük önem taşımaktadır (Yücel ve Özgül, 2020). Yenilik performansı ise yeni bir ürün ya da hizmetin örgüt tarafından kullanılma durumu şeklinde tanımlanabilir (Yavuz, 2010).

Yenilik performansı örgüt yönetiminin yenilikçi ortamı destekleme politikalarının rolü göz önüne alınarak değerlendirilmelidir (Fleacă, 2018). Örgütler, yenilikçi fırsat arayışlarında genellikle zaman, para ve diğer kaynaklara önemli miktarda yatırım yapmaktadırlar. Buradan hareketle yenilik sürecinin en temel öğesi, ticari potansiyele sahip yeni fikirlerin araştırılması olarak karşımıza çıkar (Laursen ve Salter, 2006). Yenilik performansının sektör, ülke ya da örgütler için değişik şekillerde algılanabilmesinden ötürü ölçümü için de farklı kriterler kullanılmaktadır. Bu ölçümlerde en sık kullanılan kriterlerin başında AR-GE harcamaları, gri yakalı çalışan sayısı ve alınan patent sayıları gibi göstergeler gelmektedir. Ancak yine de bu göstergelerin objektif bir sonuç ortaya koyabildiğini söylemek güçtür (Eryiğit, 2013).

Öte yandan yenilik performansını geliştirmek ve artırmak isteyen örgütlerin öğrenme yönelimli bir örgüt kültürü benimsemeleri (Avcl, 2009), rakipleriyle işbirliği ve dayanışma içerisinde olmaları (Zeng, Xie ve Tam, 2010) ve devlet kaynaklarından kesinlikle faydalanmaları gerektiği (Li, Xia ve Zajac, 2017) önerilmektedir. Ayrıca üst yönetimin; yenilikçiliğe olan destek faktörünün, yenilikçilik performansı üzerinde en etkili unsur olduğu unutulmamalıdır (Değirmencioğlu, 2006). Kayhan (2005) çalışana, projesi ile ilgili yeterli zaman ve destek verilmesi durumunda örgütün yenilik performansının artacağını savunmaktadır. Bununla birlikte dönüşümsel liderliğin, örgütsel öğrenme ve bilgi yönetimi süreci yeteneği (Imran, Ilyas, Aslam ve Rahman, 2016) ile çalışanların bağlamsal performansı üzerinde olumlu bir etkisinin olduğu (Pradhan, Jena ve Bhattacharyya, 2018) tespit edilmiştir.

Dönüşümcü ve etkileşimci liderliğin örgüt kültürüne etki ettiği (Rajabi, 2020), dönüşümcü liderliğin örgütsel inovasyon üzerinde pozitif yönlü ve anlamlı bir etkisinin olduğu ve örgütsel öğrenmenin dönüşümcü liderlik ile örgütsel inovasyon arasında kısmi aracılık rolü üstlendiği (Çağlıyan, Attar ve Külahlı, 2021) araştırmacıların bulguları arasındadır. Ek olarak dönüşümcü liderliğin örgütsel yeniliğe doğrudan etki ettiği (Jung, Chow ve Wu, 2003; Gumusluoglu ve Ilsev, 2009), etkileşimci liderliğin işten ayrılma niyetine negatif yönde (Cıranoğlu, 2020) ve örgütsel yaratıcılığa pozitif yönde etki ettiği (Hussain, Abbas, Lei, Haider ve Akram, 2017) araştırmacıların bulguları arasındadır.

Ayrıca kurumsal sosyal sorumluluk, örgütsel bağlılık (İraz, Kalfaoğlu ve Kurnaz, 2018), kurumsal girişimcilik (Umair, Abbas, Asif, Hussain ve Muhammad, 2018), yenilik stratejileri (Atakan, 2017), işbirlikleri (Güler ve Kanber, 2011), temel yetenek tabanlı yönetim modelleri (Özbağ, 2010), örgüt kültürü (Kurt, 2010), yenilik kapasitesi (Prajogo ve Ahmed, 2006), üretim yeteneği (Eren, Alpkan ve Erol, 2005), toplam kalite 
yönetimi (Prajogo ve Sohal, 2004) ve ürün kalitesinin (Prajogo ve Sohal, 2003) yenilik performansıyla pozitif yönde bir ilişkisinin olduğu çeşitli araştırmacıların bulguları arasındadır. Bunun yanı sıra farklılıkların yönetiminin örgütsel yaratıcılık ve yenilik performansına pozitif yönde etki ederek güçlendirdiği (Öğe ve Canbolat, 2019), örgüt iklimi boyutlarından yönetim desteği ve ödülün yenilik performansını etkilediği (Öztürk, 2019), konaklama işletmelerinde dışsal prestij ve işe adanmışlık ile yenilik performansı arasında pozitif yönlü bir ilişki olduğu (Balkı vd., 2020) yine araştırmacıların bulguları arasında yer almaktadır.

Literatürde Samur (2011) yenilik performansının, yeni ürün ve üretim performansı ile örgütün finansal yapısı üzerinde önemli ve olumlu etkiler yarattığını ve Zehir ve Özşahin (2008) ise stratejik karar verme hızının yenilik performansı üzerinde olumlu etki oluşturduğunu tespit etmişlerdir. Bu durum birçok kavramın, yenilik performansı üzerinde pozitif ve güçlü bir etkisinin olduğunu belirtmekle birlikte yenilik performansının dinamik ve çok boyutlu bir yönünün olduğunu da ortaya koymaktadir.

Konaklama işletmelerinin müşteriler açısından tercih nedeni olabilmelerinin bir yolu da yenilikçi adımlar atabilmesine bağlıdır. Özellikle gelenekselcilikten uzaklaşıp yenilik sürecine odaklanan dönüşümcü liderler, örgütlerin yenilik performanslarının gelişmesinde de önemli bir rol üstlenirler. Nitekim Si ve Wei (2012) araştırmalarında dönüşümcü liderlik ile yenilik performansı arasında anlamlı bir ilişki olduğunu ileri sürmüşlerdir. Bütün bu veriler ışığında belirlenen hipotezler aşağıdaki gibidir:

H1: Dönüşümcü liderlik algısının yenilik performansı algısı üzerinde olumlu etkisi vardir.

$\mathrm{H}_{2}$ : Etkileşimci liderlik algısının yenilik performansı algısı üzerinde olumlu etkisi vardır.

\section{YÖNTEM}

Araştırma nicel araştırma deseninde olup Karaman ilinde faaliyet gösteren konaklama işletmelerinde çalışan personelin dönüşümcü ve etkileşimci liderlik algılarının yenilik performansı algılarına etkisini belirlemek amacıyla kesitsel tipte planlanmıştır. Araştırma, Karaman ilinde faaliyet gösteren konaklama işletmelerinde görev yapan, araştırma tarihleri arasında aktif olarak çalışan ve araştırmaya katılmaya gönüllü personelle sinırlıdır. Ayrıca araştırma kapsamında Karamanoğlu Mehmetbey Üniversitesi'nden Etik Kurul Onay Belgesi alınmıştır.

\section{Evren ve Örneklem}

Araştırma, Karaman ilinde faaliyet gösteren 13 konaklama işletmesinde çalışan personel ile yürütülmüştür. Ancak iki konaklama işletmesi araştırmaya katılmak istememiştir. Ayrıca Karaman ili 2015 yılından beri Türkiye'nin akıllı kent projeleri için pilot bir il konumundadır. İlde, "Entegre Akıllı KenTT Projesi" kapsamında trafikten aydınlatmaya, engelli navigasyonlarından sağlık alanındaki çalışmalara kadar birçok başlıkta yenilikçi uygulamalar hayata geçirilmeye çalışılmaktadır 
(Karaman Haber, 2021). Buradan hareketle konaklama işletmelerinin de yenilik bağlamı göz önünde bulundurularak Karaman ili araştırmanın evreni olarak seçilmiştir. Örneklem hesabı yapılmamış, araştırmaya katılmaya gönüllü ve veri toplama tarihleri arasında aktif olarak çalışan tüm personel araştırma kapsamına alınmıştır. Araştırmaya katılmak istemeyen, izinli ya da gece mesaisinde bulunan personel haricinde toplamda 96 personele ulaşılmıştır. Çeşitli nedenlerle geçerli olmayan formlar araştırma kapsamına alınmadan, geçerli 82 form ile analizler gerçekleştirilmiştir. Buna göre işletmelerin genel özellikleri, çalışan sayısı, geçerli anket sayısı ve ankete dönüş oranları Tablo 1'de gösterildiği şekildedir.

Tablo 1. İşletmelerin genel özellikleri, çalışan sayısı ve geçerli form sayısı

\begin{tabular}{|c|c|c|c|c|c|c|c|c|}
\hline S.No & $\begin{array}{l}\text { Konaklama } \\
\text { İşletmesi Kodu }\end{array}$ & $\begin{array}{l}\text { Bakanlık } \\
\text { Belgeli }\end{array}$ & $\begin{array}{l}\text { Belediye } \\
\text { Belgeli }\end{array}$ & $\begin{array}{l}\text { Yild1z } \\
\text { Sayısı }\end{array}$ & $\begin{array}{l}\text { Oda } \\
\text { Sayısı }\end{array}$ & $\begin{array}{l}\text { Yatak } \\
\text { Sayisı }\end{array}$ & $\begin{array}{l}\text { Personel } \\
\text { Sayısı }\end{array}$ & $\begin{array}{l}\text { Geçerli } \\
\text { Form Sayısı }\end{array}$ \\
\hline 1 & İşletme-01 & $x$ & & 5 & 62 & 140 & 47 & 29 \\
\hline 2 & İşletme-02 & $x$ & & 2 & 44 & 92 & 5 & 4 \\
\hline 3 & İşletme-03 & $x$ & & 3 & 28 & 56 & 5 & 2 \\
\hline 4 & İşletme-04 & $x$ & & 3 & 39 & 78 & 8 & 5 \\
\hline 5 & İşletme-05 & $x$ & & 3 & 52 & 96 & 10 & 3 \\
\hline 6 & İşletme-06 & & $x$ & & 52 & 76 & 7 & 5 \\
\hline 7 & İşletme-07 & & $x$ & & 20 & 28 & 4 & 4 \\
\hline 8 & İşletme-08 & & & & 11 & 30 & 9 & 7 \\
\hline 9 & İşletme-09 & & $x$ & & 31 & 72 & 7 & 6 \\
\hline 10 & İşletme-10 & & $x$ & & 25 & 50 & 3 & 2 \\
\hline \multirow[t]{3}{*}{11} & İşletme-11 & $x$ & & 4 & 48 & 94 & 15 & 15 \\
\hline & Toplam & & & & 412 & 812 & 120 & 82 \\
\hline & Katılım oranı & 68,33 & & & & & & \\
\hline
\end{tabular}

Kaynak: KIKTM (2021)

\section{Veri Toplama Formu}

Araştırmada veri toplama formu olarak demografik bilgileri içeren 6 soru, dönüşümcü liderlik ölçeği (20 madde), etkileşimci liderlik ölçeği (16 madde) ve yenilik performansı ölçeği (5 madde) uygulanmıştır. Dönüşümcü ve Etkileşimci Liderlik Ölçeği, Avolio ve Bass (2004) tarafından Çoklu Faktör Liderlik Ölçeği (MLQ Form, 5X) olarak geliştirilmiş olup Yavuz'un (2008) araştırmasında Türkçe geçerlilik ve güvenilirliği yapılan ölçeklerden yararlanılmıştır. Yenilikçilik Performansı Ölçeği ise Calantone, Cavusgil ve Zhao (2002) tarafından geliştirilmiş ve Avcı (2009) tarafından Türkçe geçerlilik ve güvenilirliği yapılmıştır. Ölçekler beşli Likert tipte kullanılmıştır. Bu araştırmada ölçeklerin Cronbach alfa değerleri sırasıyla ,935, 805 ve ,834 olarak tespit edilmiştir.

\section{Verilerin Toplanması}

Veriler, araştırmacılar tarafından geliştirilen anket formu, Dönüşümcü Liderlik Ölçeği, Etkileşimci Liderlik Ölçeği ve Yenilikçilik Performansı Ölçeği ile Ekim-Kasım 2019 
tarihleri arasında elde edilmiştir. Anket formu araştırmacılar tarafından yüz yüze görüşme yöntemi ile toplanmıştır. Veri toplama tarihlerinde aktif olarak konaklama işletmelerinde çalışan katılımcıların uygun oldukları zamanlarda veriler toplanmıştır. Anket formunu doldurmak ortalama 10 dakika sürmüştür.

\section{BULGULAR}

\section{Demografik Bulgular}

Katılımcıların demografik özelliklerine ait bulgular Tablo 2' de verilmiştir. Buna göre katılımcıların \%54,9'u 30 yaş ve altında, \%67,1'i erkek, \%41,5'i lise mezunu, \%50'si bekar, \%42,7'si 0-5 yıl arası iş tecrübesine sahip ve \%29,3'ü resepsiyon hizmetlerinde görev yapmaktadır.

Tablo 2. Katılımcıların demografik özellikleri $(\mathrm{n}=82)$

\begin{tabular}{lccc}
\hline Demografik Özellikler & Sayı $(\%)$ & Demografik Özellikler & Sayı (\%) \\
\hline Yaş & $45(54,9)$ & Medeni Durum & $41(50,0)$ \\
30 yaş ve altı & Evli & $41(50,0)$ \\
31 - 40 yaş & Bekar & \\
41 yaş ve üzeri & $16(19,5)$ & İş Tecrübesi & $35(42,7)$ \\
Cinsiyet & & $0-5$ yıl & $23(28,0)$ \\
$\quad$ Kadın & $27(32,9)$ & $6-10$ yıl & $24(29,3)$ \\
Erkek & $55(67,1)$ & 11 yıl ve üzeri & \\
& & Çalışıllan Bölüm & $24(29,3)$ \\
Eğitim Durumu & Resepsiyon & $16(19,5)$ \\
İlköğretim & $23(28,0)$ & Mutfak & $22(26,8)$ \\
Lise & $34(41,5)$ & Kat Hizmetleri & $20(24,4)$ \\
Üniversite & $25(30,5)$ & Diğer &
\end{tabular}

\section{Dönüşümcü Liderlik Ölçeği Açıklayıcı Faktör Analizi}

Açıklayıcı Faktör Analizi (AFA), aralarında ilişki olduğu tahmin edilen çok sayıdaki değişken arasındaki ilişkilerin anlaşılabilmesi adına değişkenlerin daha az sayıdaki ana boyutlara indirgenebilmesi amacıyla kullanılan bir analiz tekniğidir (Doğan ve Başokçu, 2010). Bu analizde tüm ölçekler için Hair, Anderson ve Tatham'ın (1998) önerdiği şekliyle faktör yükü 0,40 ve üzeri olan ifadeler bir arada toplanmıştır. Ölçeklerin her birinde kullanılan KMO değerinin 0,70'in üzerinde tespit edilmesi değişkenlerin birbiri ile ilişkili olduğunu ve ortak faktörleri paylaştığına işarettir. Ölçekler üzerinde temel bileşenler faktör analizi gerçekleştirilmiş olup korelasyon matrisinin birim matrise eşit olup olmadığı hipotezi ise Bartlett's Test of Sphericity testi ile test edilmiştir (Çetinkaya ve Canbolat, 2020). Dönüşümcü liderlik ölçeğine (Tablo 3) uygulanan AFA'nde KMO değeri 0,868 olarak tespit edilmiştir. Bu değerin "iyi" düzeyde olduğu (Kaiser, 1974) görülmüştür. Bartlett's Test of Sphericitytesti ise istatistiki olarak anlamlı bir $\chi 2$ sonucu ortaya koyarak $(\chi 2=1209,90, \mathrm{df}=171, \operatorname{Sig}<000)$ faktör analizinin değişkenlere uygulanabileceği konusunda destek sunmuştur. 
Tablo 3. Dönüşümcü liderlik ölçeği açılayıcı faktör analizi (n=82)

\begin{tabular}{lll}
\hline KMO ve Bartlett's Testi & Kaiser-Meyer-Olkin örneklem yeterliliği = &, 868 \\
(Bartlett's Test of Sphericity) & Yaklaşık Ki-kare $\left(\chi^{2}\right)=$ & 1209,902 \\
& df (serbestlik derecesi) $=$ & 171 \\
Sig. $=$ & 0,000
\end{tabular}

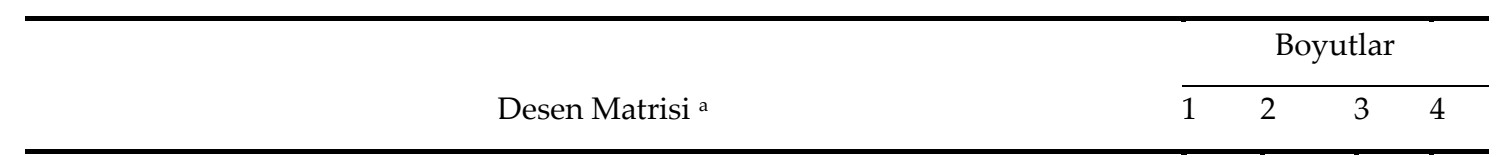

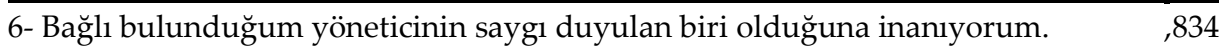

3- Böyle bir yöneticiye sahip olduğum için gurur duyuyorum. 825

1- Bağlı bulunduğum yönetici işletmenin veya bölümün amaçlara ulaşacağına ${ }^{7} 797$ inandığını ve güvendiğini ifade eder.

2- Bağlı bulunduğum yönetici zorluklar karşısında yılmaz $\quad$,797

4- Bağlı bulunduğum yöneticinin ahlaki standartlar yönünden iyi bir model ${ }_{, 740}$ olduğunu düşünüyorum.

5- Bağlı bulunduğum yönetici mesleki değerlerden sık sık söz eder.

,738

9- Astlarını önemli konular hakkında bilinçli olmaya teşvik eder.

19- Bağlı bulunduğum yönetici astlarına işlerini yapmak için yeni yollar önerir.

15- Bağlı bulunduğum yönetici kendini geliştirmek yönünde ilgi duyduğu alanların dişındaki konulara da zaman ayırmaktadır.

18- Bağlı bulunduğum yönetici astlarını geliştirmek için onlara yol gösterir ve onları eğitir.

17- Bağlı bulunduğum yönetici astlarının hepsini birlikte ele almaz, her birine ayrı bir davranış şekli belirler.

14- Bağlı bulunduğum yönetici astlarının mesleki konularla ilgili farklı bakış açıları geliştirmeleri yönünde teşvik eder.

13- Bağlı bulunduğum yönetici günlük sorunlarla ilgili olarak, iş görene farklı görüş açları önerir.

8- Yöneticim “ben gidiyorum var mı gelen” dediğinde tüm astların onu izleyeceğine inaniyorum.

7- Yöneticimin ilişkilerinde kendine güvenen, güçlü bir kişiliği olduğuna inaniyorum.

12- Yöneticim problemleri çözerken tüm alternatifleri defalarca gözden geçirir.

10- Bağlı bulunduğum yönetici olumlu ve pozitif konuşmayı tercih eder.

20- Bağlı bulunduğum yönetici astlarının kişisel arzu, ihtiyaç ve yeteneklerini, astlarıyla olan ilişkilerinde hep göz önünde bulundurur.

16- Bağlı bulunduğum yönetici çalıştığı kişilerin güçlü taraflarına odaklanır ve kendilerine destek olur. 


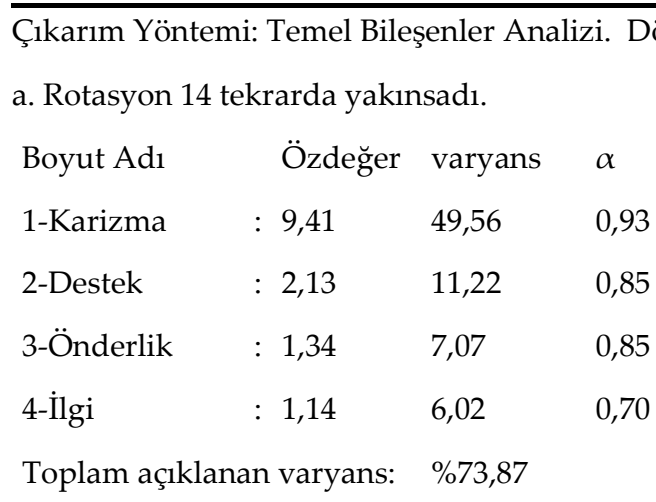

Dönüşümcü liderlik ölçeği AFA, ölçeğin dört boyutu olduğunu önermektedir. Bu boyutlar; karizma, destek, önderlik ve ilgi şeklinde isimlendirilmiştir. Tablo 3'de dönüşümcü liderliğin özdeğer, açıklanan varyans ve güvenirlik $(\alpha)$ katsayıları bulunmaktadır. Boyutların 1'in üzerinde özdeğere sahip olduğu ve açıklanan toplam varyansın \%73,87'sini temsil ettiği görülmektedir. Ayrıca boyutların Cronbach alfa değerleri yüksek iç tutarlılığın sağlandığını ortaya koymaktadır. 11 numaralı madde 0,40 'ın altında yükleme değerine sahip olduğundan analizden çıkarılmıştır. Boyutlar için bileşik değerli değişkenler üretildiğinden ilerleyen analizlerde bu bileşik değerler baz alınmıştır.

\section{Etkileşimci Liderlik Ölçeği Açıklayıcı Faktör Analizi}

Etkileşimci liderlik ölçeği AFA (Tablo 4), KMO değeri 0,732 değerinde olup “iyiye yakın" düzeydedir (Kaiser, 1974). Bartlett's Test of Sphericity testi ise istatistiki olarak anlamlı bir $\chi 2$ sonucu ortaya koyarak $(\chi 2=839,939, \mathrm{df}=91$, Sig<000) faktör analizinin ilgili değişkenlere uygulanabileceğine dayanak sağlamıştır. Etkileşimci liderlik ölçeği AFA, ölçeğin üç boyutu olduğunu önermektedir. Boyutlar; koşullandırma, gelenekselcilik ve denetim şeklinde isimlendirilmiştir. Ölçek boyutlarının özdeğer, açıllanan varyans ve güvenirlik $(\alpha)$ katsayıları Tablo 4 'te sunulmuştur. Boyutlar 1'in üzerinde özdeğerde ve toplam varyansın \%63,10'unu temsil etmektedirler. Boyutların Cronbach alfa değerleri iç tutarlığın sağlandığı ortaya koymaktadır. 25 ve 30 numaralı maddeler farklı boyutlarda birbirine yakın değerde eşanlı yüklemede bulundukları için analizden çıkarılmıştır. Etkileşimci liderlik ölçeği AFA bulguları neticesinde bileşik değerli değişkenler üretilerek ilerleyen analizlerde bu bileşik değerler baz alınmıştır. 
Tablo 4. Etkileşimci liderlik ölçeği açıklayıcı faktör analizi ( $\mathrm{n}=82)$

\begin{tabular}{lll}
\hline KMO ve Bartlett's Testi & Kaiser-Meyer-Olkin örneklem yeterliliği = &, 732 \\
(Bartlett's Test of Sphericity) & Yaklaşık Ki-kare $\left(\chi^{2}\right)=$ & 839,939 \\
& df (serbestlik derecesi) $=$ & 91 \\
& Sig. $=$ & 0,000 \\
\hline
\end{tabular}

\begin{tabular}{llll}
\hline & Boyutlar \\
\cline { 2 - 3 } & Desen Matrisi a & \multicolumn{3}{c}{ Boy } & 2 & 3 \\
\hline
\end{tabular}

24- Astlarının başarıları sonucunda neler elde edeceklerine, astlarının dikkatini çeker. , 831

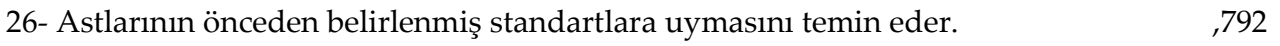

23- Bağlı bulunduğum yönetici astlarının başarılarını ödüllendirir.

21- Bağlı bulunduğum yönetici astlarının hangi davranışının ne şekilde, 526 ödüllendirileceğini önceden belirler ve net şekilde ortaya koyar.

33- Bir şey tamamen bozulmadıkça ona müdahale etmez.

34- Bölümdeki bir problem, ancak kronik bir hal aldıktan sonra, problemi çözmeye çalışır.

35- Bağlı bulunduğum yönetici katılımcılıktan kaçınır.

29- Bağlı bulunduğum yönetici sorumluluk almaktan kaçınır.

32- Yöneticim mecbur kalmadıkça karar vermekten kaçınır.

36- Bir kişiye görev verileceğini duyduğunda fazla göz önünde dolaşmaz.

,651

27- Astlarının hatalarını yakın takibe alır.

31- Bağlı bulunduğum yönetici faaliyetlerin aksaması durumunda, kendisi haberdar edildiği takdirde müdahale eder.

28- Astlarının görev performanslarını denetler ve standartlardan sapmalar oldukça müdahale eder.

22- Bağlı bulunduğum yönetici astlarının göreve yönelik çabalarını destekler.

Çıkarım Yöntemi: Temel Bileşenler Analizi. Döndürme Yöntemi: Direct Oblimin

a. Rotasyon 11 tekrarda yakınsadı.

$\begin{array}{llll}\text { Boyut Adı } & \text { Özdeğer } & \text { varyans } & \alpha \\ \text { 1-Koşullandırma } & 4,031 & 28,78 & 0,75 \\ \text { 2-Gelenekselcilik } & 3,658 & 26,14 & 0,88 \\ \text { 3-Denetim } & 1,146 & 8,18 & 0,79 \\ \text { Toplam açıklanan varyans: } & \% 63,10 & \end{array}$

\section{Yenilik Performansı Ölçeği Açıklayıcı Faktör Analizi}

Yenilik performansı ölçeği (Tablo 5), AFA'nde KMO değeri 0,772 olarak tespit edilmiş olup değer "iyiye yakın" düzeydedir (Kaiser, 1974). Bartlett's Test of Sphericity testi istatistiki olarak anlamlı bir $\chi 2$ sonucu $(\chi 2=162,997, \mathrm{df}=10, \mathrm{Sig}<000)$ ortaya koyarak faktör analizinin değişkenlere uygulanabileceğini doğrulamıştır.

Yenilik performansı ölçeği AFA, ölçeğin tek boyutu olduğunu önermiştir. Boyut yenilik performansı olarak isimlendirilmiştir. Yenilik performansı boyutunda özdeğer 3,034 , toplam açıklanan varyans \%60,69 ve Cronbach alfa değeri 0,84 (5 madde) olarak 
tespit edilmiştir. Bu tespite göre sonraki analizler bileşik değişken baz alınarak gerçekleştirilmiştir.

Tablo 5. Yenilik performansı ölçeği açıklayıcı faktör analizi (n=82)

\begin{tabular}{|c|c|c|}
\hline KMO ve Bartlett's Testi & Kaiser-Meyer-Olkin örneklem yeterliliği = & ,772 \\
\hline \multirow[t]{5}{*}{ (Bartlett's Test of Sphericity) } & Yaklaşık Ki-kare $\left(\chi^{2}\right)=$ & 162,997 \\
\hline & df $($ serbestlik derecesi $)=$ & 10 \\
\hline & Sig. $=$ & 0,000 \\
\hline & & Boyut \\
\hline & Bileşen Matrisi a & 1 \\
\hline \multicolumn{2}{|c|}{ 40- İşletmemiz pazarda yeni mal ve hizmetleri ilk sunan işletmeler arasındadır. } & ,830 \\
\hline \multicolumn{2}{|c|}{ 38- İşletmemiz işleri başarmak için yeni yollar dener. } & ,824 \\
\hline \multicolumn{2}{|c|}{ 39- İşletmemiz faaliyetlerini geliştirecek yeni metotlar dener. } & 781 \\
\hline \multicolumn{2}{|c|}{ 41- İşletmemizin ortaya çıkardığı yeni mal ve hizmetler son 3 yıl içinde artmıştır. } & 741 \\
\hline \multicolumn{2}{|c|}{ 37- İşletmemiz sık sık yeni fikirler dener. } & 713 \\
\hline \multicolumn{3}{|c|}{ Çıkarım Yöntemi: Temel Bileşenler Analizi. Döndürme Yöntemi: Direct Oblimin } \\
\hline \multicolumn{3}{|c|}{ a. Rotasyon 1 tekrarda yakınsadı (ortak noktada benzeşti). } \\
\hline Boyut Ad 1 & varyans & \\
\hline 1-Yenilik Performansı : 3,034 & 60,69 & \\
\hline Toplam açıklanan varyans: & $\% 60,69$ & \\
\hline
\end{tabular}

\section{Doğrulayıcı Faktör Analizi}

AFA'nin desteklenmesi maksadı ile üretilen boyutların doğrulanması adına doğrulayıcı faktör analizi (DFA) uygulanmıştır. DFA, önceden belirlenmiş bir yapının doğrulanmasına olanak sağlayan bir analiz tekniğidir (Yaşlıŏlu, 2017). Bu analiz, yenilik performansı değişkeni tek boyuttan oluştuğu için yalnızca dönüşümcü liderlik ve etkileşimci liderlik değişkenlerine uygulanmış olup bulgular Şekil 1 ve Şekil 2' deki gibidir.

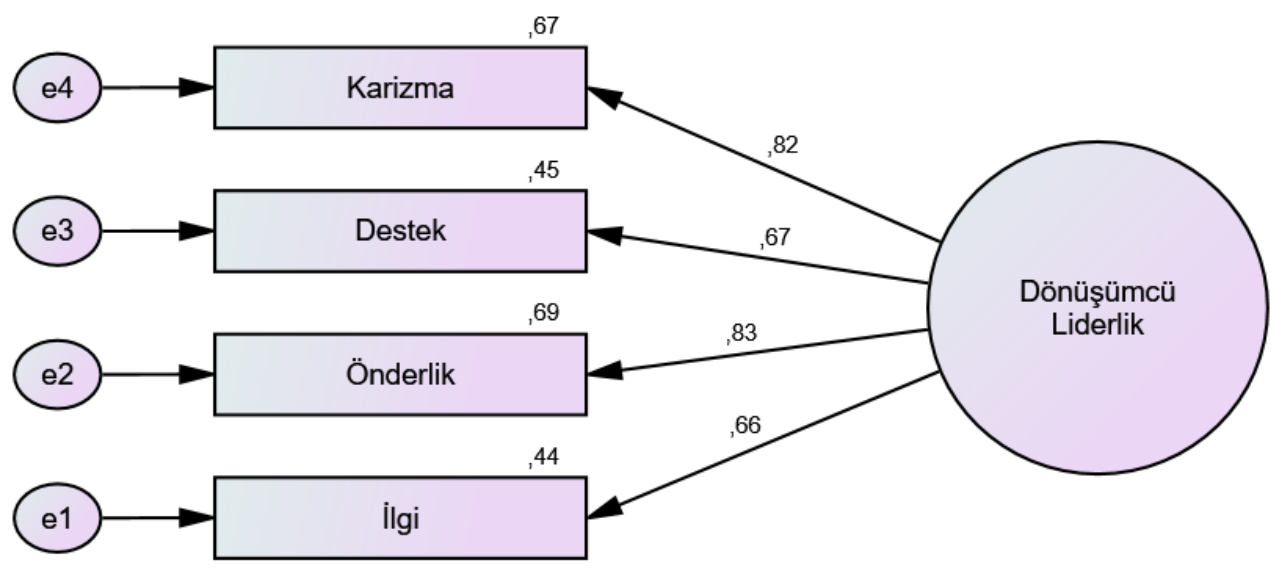

Şekil 1. Dönüşümcü liderlik ölçeği doğrulayıcı faktör analizi sonuçları 


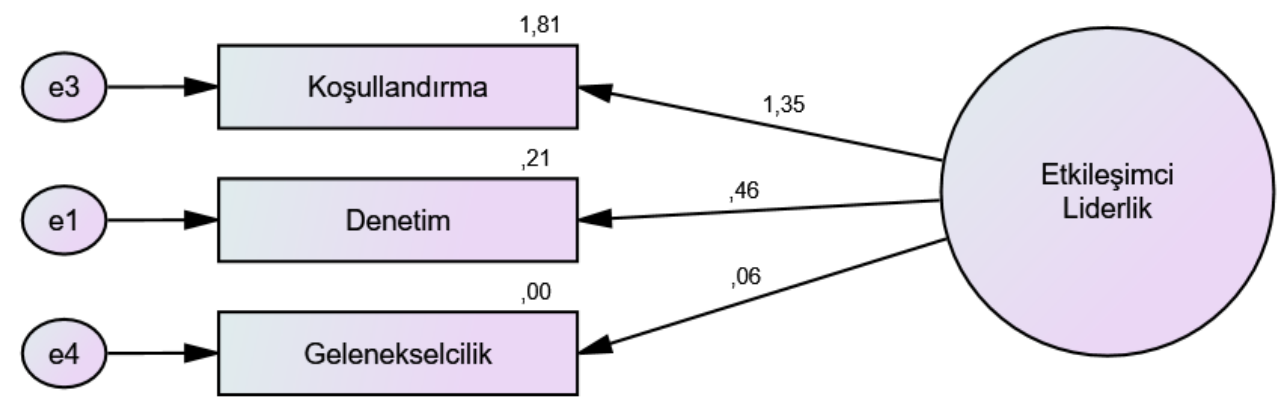

Şekil 2. Etkileşimci liderlik ölçeği doğrulayıcı faktör analizi sonuçları

Şekil 1 incelendiğinde faktör yüklerinin 0,66-0,83 aralığında oluştuğu görülmektedir. Ayrıca Tablo 7'deki uyum indekslerinin referans değerler arasında yer aldığı tespit edilmiştir. Şekil 2'deki etkileşimci liderlik ölçeği DFA analizi bulgularına göre "gelenekselcilik" boyutunun çok düşük değerde $(0,06<0,40)$ yüklendiği görülmüş ve sonraki analizlerde bu boyut kullanılmamıştır. Tablo 6'da uyum iyiliği indekslerine yer verilmiş olup DFA sonucuna göre boyutların güvenilir olduğu saptanmıştır.

Tablo 6. Uyum iyiliği indeksleri

\begin{tabular}{llll}
\hline Uyum İyiliği İndeksleri & $\begin{array}{l}\text { Referans } \\
\text { Değerler }\end{array}$ & $\begin{array}{l}\text { Dönüşümcü } \\
\text { Liderlik Ölçeği }\end{array}$ & $\begin{array}{l}\text { Etkileşimci } \\
\text { Liderlik } \\
\text { Ölçeği }\end{array}$ \\
\hline CFI (Karşılaştırmalı Uyum iyiliği indeksi) & $\geq 0,90$ & 1,000 & 1,000 \\
IFI (Artırımlı Uyum İyiliği İndeksi) & $\geq 0,90$ & 1,010 & 1,000 \\
GFI (Uyum İyiliği İndeksi) & $\geq 0,90$ & 0,995 & 1,000 \\
RMSEA (Yaklaşım Hatasının Kök Ortalama Karesi) & $\leq 0,08$ & 0,000 & 0,039 \\
$X^{2} /$ df & $\leq 3$ & 0,408 & 0,000
\end{tabular}

\section{Çoklu Regresyon Analizi}

Regresyon analizinden önce değişkenler arasındaki ilişkiyi ortaya koyabilmek adına korelasyon analizi yapılmıştır. Korelasyon analizi, en az iki değişken arasındaki olası ilişki ve bu ilişkinin yönü ile şiddetinin tespiti amacıyla kullanılan bir analiz yöntemidir (Gürbüz ve Şahin, 2015). Dönüşümcü liderlik ölçeği, etkileşimci liderlik ölçeği ve yenilik performansı ölçeği AFA bileşik değişkenleri arasındaki doğrusal ilişki doğrultusunda Pearson korelasyon analizi sonuçları Tablo 7'de gösterilmiştir.

Tablo 7. Pearson korelasyon analizi $(n=82)$

\begin{tabular}{llllllllll}
\hline & Ort. & Std. Hata & 1 & 2 & 3 & 4 & 5 & 6 & 7 \\
\hline 1- Karizma & 4,127 & 0,855 & 1 & & & & & & \\
2- Destek & 4,069 & 0,712 &, $543^{* *}$ & 1 & & & & & \\
3- Önderlik & 4,122 & 0,848 &, $687^{* *}$ &, $545^{* *}$ & 1 & & & & \\
4- İlgi & 3,951 & 0,894 &, $526^{* *}$ &, $491^{* *}$ &, $545^{* *}$ & 1 & & & \\
5- Koşullandırma & 3,811 & 0,778 &, $588^{* *}$ &, $608^{* *}$ &, $602^{* *}$ &, $576^{* *}$ & 1 & & \\
6- Denetim & 4,043 & 0,791 &, $628^{* *}$ &, $419^{* *}$ &, $571^{* *}$ &, $655^{* *}$ &, $623^{* *}$ & 1 & \\
7-Yenilik Performans1 & 3,980 & 0,764 &, $245^{*}$ &, $395^{* *}$ &, $248^{*}$ &, 136 &, $267^{*}$ &, 168 & 1 \\
\hline
\end{tabular}


Korelasyon analizi sonuçlarına göre yenilik performansı değişkeninin dönüşümcü liderliğin ilgi ve etkileşimci liderliğin denetim boyutu ile ilişkinin olmadığı tespit edilmiştir. Bunların haricinde yer alan diğer değişkenlerin orta ve yüksek düzeyde anlamlı ve pozitif yönlü ilişkili olduğu görülmüsstür. Aritmetik ortalama aralıklarının ise genellikle yüksek ve çok yüksek düzeyde olduğu belirlenmiştir.

Çoklu regresyon analizi ise bir bağımlı değişken üzerinde birden çok bağımsız değişkenin etkisinin incelenmesi amacıyla kullanılan bir analiz yöntemidir (Gürbüz ve Şahin, 2015). Analiz sonuçlarına Tablo 8' de yer verilmiştir.

Tablo 8. Dönüşümcü ve etkileşimci liderliğin yenilik performansına etkisi regresyon analizi

\begin{tabular}{lllllllll}
\hline Bağımlı Değişken & R & F & Sig. & Bağımsız Değişken & B & t & & Sig. \\
& Square & & & & & & \\
\hline Yenilik Performansı & 0,109 & 4,818 &, $011^{\text {b }}$ & Dönüşümcü Liderlik &, 398 & 2,120 & 0,037 \\
& & & & Etkileşimci Liderlik &, 033 &, 184 & 0,854 \\
& & & & &
\end{tabular}

Tablo 8'de yer alan çoklu regresyon analiz sonuçlarına göre dönüşümcü liderlik algısının yenilik performansı algısına pozitif yönde etki ettiği $(p<0,05)$, etkileşimci liderlik algısının ise yenilik performansı algısı üzerinde anlamlı bir etkisinin olmadığı ( $\mathrm{p}>0,05)$ tespit edilmiştir. Bu durumda $\mathrm{H}_{1}$ kabul edilirken $\mathrm{H}_{2}$ reddedilmiştir.

\section{SONUÇ, TARTIŞMA VE ÖNERILLER}

Araştırma, Karaman il genelinde faaliyet gösteren konaklama işletmeleri personeli ile yürütülmüştür. Avolio ve Bass (2004) tarafından geliştirilen dönüşümcü ve etkileşimci liderlik ölçeği dörder boyut olarak belirlenmiştir. Yavuz (2008) ve Özmen (2015) araştırmalarında ölçekleri dört boyutlu olarak ele almışlardır. Ancak bu araştırmada gerçekleştirilen açıklayıcı faktör analizi doğrultusunda dönüşümcü liderliğin yine dört boyutu ortaya çıssa da yoğun turizm potansiyeli olmayan konaklama işletmelerinde faktör yapısının değiştiği sonucuna ulaşılabilir. Benzer şekilde etkileşimci liderlik ölçeği de bu çalışmada üç faktör ile açıklanabilmektedir. Yavuz (2008) araştırmasını Antalya, Aydın ve Muğla'daki dört ve beş yıldızlı otellerle yürütmüştür. Bölgesel olduğu düşünülen bu farklılık gerek yüksek yıldız seviyeleri gerekse bölgenin turizm bölgesi olmasından kaynaklanabilir. Nihayetinde Karaman'daki konaklama işletmelerinin toplam yatak kapasitesi sadece Antalya'daki tek bir otelin yatak kapasitesine eş olabilmektedir. Rajabi (2020) ise sağlık çalışanları ile yürüttüğü araştırmasında açıklayıcı faktör analizi sonuçlarına göre dönüşümcü liderliğin dört ve etkileşimci liderliğin üç boyut önerdiğini değerlendirmiştir. Bu araştırma bulguları da Rahabi'nin (2020) araştırma bulguları ile örtüşmektedir.

Araştırma bulgularına göre çalışanların dönüşümcü liderlik algısının yenilik performansı algısına pozitif yönde etki ettiği tespit edilerek $\mathrm{H}_{1}$ kabul edilmiştir. Si ve Wei (2012) ile Firat ve Yeşil (2020) tarafından gerçekleştirilen araştırmalarda da dönüşümcü liderliğin yenilik performansını pozitif yönde etkilediği tespit edilmiştir. $\mathrm{Bu}$ durum bulgularımızla örtüşmekte ve konaklama işletmelerinde de aynı etkinin geçerli olduğunu ortaya koymaktadır. Araştırmanın bir diğer bulgusu ise etkileşimci liderlik algısının yenilik performansı algısı üzerinde anlamlı bir etkisinin olmadığı 
yönündedir. $\mathrm{Bu}$ durumda $\mathrm{H}_{2}$ reddedilmiştir. Benzer kavramlarla ilintisi incelendiğinde dönüşümcü liderliğin negatif inovasyon ile ters yönlü bir ilişkide olduğu ve etkileşimci liderliğin ise negatif inovasyonu artırdığı görülmüştür (Tokmak, 2019). Bu durum iki liderlik tipinin de negatif de olsa inovasyona etki ettiğini ortaya koymaktadır. Ancak dönüşümcü ve etkileşimsel liderliğin birlikte bağımsız değişken olduğu araştırmalarda dönüşümcü liderliğin etkisi görülürken etkileşimci liderliğin etkisiz kalabildiği de görülebilmektedir. Örneğin dönüşümcü liderliğin örgütsel vatandaşlık davranışı üzerinde etkisi olurken etkileşimci liderliğin örgütsel vatandaşlık davranışı üzerinde etkisinin olmadığı (Biçer, 2019), konaklama işletmelerinde dönüşümcü liderlik ile sosyal sermaye arasında pozitif yönlü anlamlı bir ilişki tespit edilirken etkileşimsel liderlik algısının yapısal sosyal sermayeyi azalttığı (Ayhün ve Celep, 2019) araştırmacıların bulguları arasında yer almaktadır.

Sonuç olarak dönüşümcü liderlik bu araştırmada olduğu gibi birçok araştırmada da bağımlı değişkeni olumlu yönde etkilerken etkileşimci liderliğin ise bir takım değişkenlere etki etmediği görülmektedir. Nitekim etkileşimci liderler, eski yaklaşım ve geleneklere daha çok bağlıdırlar (Ersoydan, 2014). Aynı zamanda bir taraftan yenilik ve risk alma olgularından kaçınırlarken diğer taraftan yüksek çıktılara ulaşmayı da amaçlamaktadırlar (McMurray vd., 2012). Araştırma bulguları da literatürdeki bu tanımları destekler şekilde sonuçlanmıştır. Öte yandan yenilik performansına etki eden birçok değişkenin olduğu gerek bu çalışmada gerek literatürde desteklenen bir ifadedir. Konaklama işletmelerinde tüm bu sonuçlar dikkate alındığında uygulayıcılar için yönetim kadrolarında dönüşümcü liderlik tipindeki yöneticilerin tercih edilmesi ve teorisyenler için araştırma sonuçlarının karşılaştırılabilmesi adına benzer çalışmaların farklı illerde ve yüksek örnekleme sahip konaklama işletmelerinde tekrarlanarak sonuçlarının mukayeseli olarak incelenmesi, farklı liderlik tiplerinin konaklama işletmelerinde yenilik performansına olası etkilerinin araştırılması, konaklama işletmelerindeki mevcut yöneticilerin göstereceği liderlik özelliklerinde etkileşimci liderlik tarzından kaçınmaları ve daha çok dönüşümsel liderlik tarzını benimsemeleri gerektiği önerilmektedir. Son olarak konaklama işletmelerinde yenilikçi uygulamaların güncel bir şekilde takip edilerek yenilik performansının artırılabileceği söylenebilir.

Hakem Değerlendirmesi: Dış bağımsız.

Teşekkür: Katkılarından dolayı hakemlere teşekkür ederiz.

Destek Bilgisi: Herhangi bir kurum ve/veya kuruluştan destek alınmamıştır.

Çıkar Çatışması: Yazarlar arasında çıkar çatışması yoktur.

Etik Onayı: Bu çalışmanın tüm hazırlanma süreçlerinde etik kurallara riayet edildiğini yazar(lar) beyan eder. Aksi bir durumun tespiti halinde Güncel Turizm Araştırmaları
Dergisi'nin hiçbir sorumluluğu olmayıp, tüm sorumluluk makale yazar(lar)ına aittir.

Bilgilendirilmiş Onam Formu: Tüm taraflar kendi rızaları ile çalışmaya dâhil olmuşlardır. Etik Kurul Onayı: Karamanoğlu Mehmetbey Üniversitesi Bilimsel Araştırma ve Yayın Etik Kurulundan 24.02.2021 tarih ve 6527 sayılı yazı ile izin alınmıştır.

Araştırmacıların Katkı Oranı: Yazarlar çalışmaya eşit oranda katkı sağlamıştır.

Veri Kullanılabilirlik Beyanı: Araştırma verileri paylaşılmamıştır. 


\section{KAYNAKÇA}

Atakan, S. C. (2017). Yenilik Stratejilerinin Yenilik Performansı Üzerindeki Etkisi ve Bir Uygulama, (Yayınlanmamış Yüksek Lisans Tezi), İstanbul Ticaret Üniversitesi, Sosyal Bilimler Enstitüsü, İstanbul.

Avcı, U. (2009). Öğrenme yönelimliliğin yenilik performansı üzerine etkisi: Muğla mermer sektöründe bir inceleme. ZKÜ Sosyal Bilimler Dergisi, 5(10), 121-138.

Avolio, B. J. ve Bass, B. M. (2004). Multifactor leadership questionnaire (TM). Inc. Menlo Park, CA.: Mind Garden.

Ayhün, S. E. ve Celep, O. (2019). Dönüşümsel ve etkileşimsel liderlik tarzlarının sosyal sermaye ve lider-üye etkileşimine etkisi: Otel işletmelerinde bir araştırma. Girişimcilik ve Kalkınma Dergisi, 14(2), 133-152.

Bakan, İ., Erşahan, B. Büyükbeşe, T, Doğan, İ. F. ve Kefe, İ. (2015). Dönüşümcü ve etkileşimci liderlik ile öğretmenlerin tükenmişlik düzeyleri arasındaki ilişki. International Journal of Economic and Administrative Studies, 7(14), 201-222.

Balkı, S., İlhan, İ. ve Özkoç, A. G. (2020). Mutfak çalışanlarında algılanan dışsal prestij ve işe adanmışlığın yenilik performansına etkisi: Nevşehir ilinde bir uygulama. Ömer Halisdemir Üniversitesi İktisadi ve İdari Bilimler Fakültesi Dergisi, 13(3), 401-412.

Bass, B. M . (1990). From transactional to transformational leadership: Learning to share the vision. Organizational Dynamics. 19(3), 19-31.

Bass, B. M. ve Riggio, R. E. (2008). Transformational Leadership. London: Lawrence Erlbaum Associates Publishers.

Biçer, T. (2019). Dönüşümcü ve Etkileşimci Liderliğin Örgütsel Vatandaşlık Davranışı Üzerindeki Etkileri, (Yayınlanmamış Yüksek Lisans Tezi), Marmara Üniversitesi, Sosyal Bilimler Enstitüsü, İstanbul.

Calantone, R. J., Cavusgil, S. T. ve Zhao, Y. (2002). Learning orientation, firm innovation capability, and firm performance. Industrial Marketing Management, 31(6), 515-524.

Cıranoğlu, M. (2020). Etkileşimci liderlik yaklaşımının hemşirelerin işten ayrılma niyetlerine etkisi ve işten ayrılma niyetinin demografik faktörlerle ilişkisi: Bursa ilinde özel hastanelerde bir alan araştırması. Eskişehir Osmangazi Üniversitesi İ̈BF Dergisi, 15(1), 61-80.

Conger, J. A. (1999). Charismatic and transformational leadership in organizations. The Leadership Quarterly, 10(2), 145-179.

Çağlıyan, V., Attar, M. ve Külahlı, S. (2021). Dönüşümcü liderliğin, örgütsel inovasyon üzerindeki etkisinde örgütsel öğrenmenin aracı rolü. Eskişehir Osmangazi Üniversitesi İ̈BF Dergisi. 16(1), 124-145.

Çetinkaya, A. Ş. ve Canbolat, M. A. (2020). Koçluk ve mentorluk ile girişimcilik niyeti arasındaki ilişkide KOSGEB desteklerinin rolü. Girişimcilik ve İnovasyon Dergisi, 9(2), 94-127.

Değirmencioğlu, Ç. (2006). Kobilerde Organizasyonel Becerilerin Yenilikçilik Performansına Etkisi, (Yayınlanmamış Yüksek Lisans Tezi), İstanbul Teknik Üniversitesi, Fen Bilimleri Enstitüsü, İstanbul. 
Doğan, N. ve Başokçu, T. O. İstatistik tutum ölçeği için uygulanan faktör analizi ve aşamalı kümeleme analizi sonuçlarının karşılaştırılması. Eğitimde ve Psikolojide Ölçme ve Değerlendirme Dergisi, 1(2), 65-71.

Dönmez, S. (2014). Developing a Likert-Type Measure to Assess Transformational and Transactional Leadership Styles in Turkey, (Unpublished Master's Thesis), Middle East Technical University, The Graduate School of Social Sciences, Ankara.

Eren, E., Alpkan, L. ve Erol, Y. (2005). Temel fonksiyonel yeteneklerin firmanın yenilik ve finansal performansına etkileri, İstanbul Ticaret Üniversitesi Sosyal Bilimler Dergisi, 4(7), 201-224.

Ersoydan, M. Y. (2014). Koro Şeflerinin Dönüşümcü ve Etkileşimci Liderlik Davranışlarının İncelenmesi, (Yayınlanmamış Sanatta Yeterlilik Tezi), Süleyman Demirel Üniversitesi, Güzel Sanatlar Enstitüsü, Isparta.

Eryiğit, N. ve Ar, İ. M. (2013). İnsan Kaynakları Yönetimi Uygulamalarının Yenilik Performansına Etkisi: ISO 1000 Uygulaması, (Yayınlanmamış Doktora Tezi). Karadeniz Teknik Üniversitesi, Sosyal Bilimler Enstitüsü, Trabzon.

Fırat, İ. ve Yeşil, S. (2020). Dönüşümcü liderlik özelliklerinin işletmenin yenilik yeteneği ve performansı üzerindeki etkisi. Beykent Üniversitesi Sosyal Bilimler Dergisi, 13(2), 4057.

Fleacă, B. (2018). Comparative analysis of european and global innovation performance barometers. TEM Journal, 7(3), 589-596.

Gumusluoglu, L. ve Ilsev, A. (2009). Transformational leadership, creativity, and organizational innovation. Journal of Business Research, 62(4), 461-473.

Güler, E. Ö. ve Kanber S. (2011). İnovasyon aktivitelerinin inovasyon performansı üzerine etkileri: İmalat sanayii uygulaması. Ç.Ü. Sosyal Bilimler Enstitüsü Dergisi, 20(1), 61-76.

Gürbüz, S. ve Şahin, F. (2015). Sosyal Bilimlerde Araştırma Yöntemleri. (2.Baskı), Ankara: Seçkin Yayıncılık.

Hair, J. F., Anderson, R. E. ve Tatham, R. (1998). Multivariate Data Analysis with Readings, (2nd and 4th Ed.). London: Macmillan Publishing Company.

Hussain, S. T., Abbas, J., Lei, S., Haider, M. J. ve Akram, T. (2017). Transactional leadership and organizational creativity: Examining the mediating role of knowledge sharing behavior. Cogent Business \& Management, 4(1), 1-11.

Imran, M. K., Ilyas, M., Aslam, U. ve Rahman, U. U. (2016) Organizational learning through transformational leadership. The Learning Organization, 23(4), 232-248.

İraz, R., Abul, A. ve Kurnaz, G. (2017). Çalışanların kurumsal sosyal sorumluluk algısının yenilikçilik performansı ile ilişkisi: Konya' da tekstil işletmesi çalışanları üzerinde bir araştırma. Sosyal Ekonomik Araştırmalar Dergisi, 17(30. Yıl Özel Sayıs1), 35-49.

İraz, R., Kalfaoğlu, S. ve Kurnaz, G. (2018). Kurumsal sosyal sorumluluk ve inovasyon performansının örgütsel bağlılığa etkisi. Selçuk Üniversitesi Sosyal Bilimler Meslek Yüksekokulu Dergisi, 21(2), 393-406.

İşcan, Ö. F. (2006). Dönüşümcü/etkileşimci liderlik alg1sı ve örgütsel özdeşleşme ilişkisinde bireysel farklılıkların rolü. Akdeniz İ̈BF. Dergisi, (11), 160-177. 
Jung, D. I., Chow, C. ve Wu, A. (2003). The role of transformational leadership in enhancing organizational innovation: Hypotheses and some preliminary findings. The Leadership Quarterly, 14(4-5), 525-544.

Kaiser, H.F. (1974), An index of factorial simplicity. Psychometrika, 39(1), 31-36.

Kanungo, R. N. (2009). Ethical values of transactional and transformational leaders. Canadian Journal of Administrative Sciences, 18(4), 257-265.

Karaman Haber, Akıllı Kent Nedir?, https://www.karamandan.com/m-11-30955.html, Erişim tarihi: 27 Şubat 2021.

Karip, E. (1998). Dönüşümcü liderlik. Kuram ve Uygulamada Eğitim Yönetimi Dergisi, 4(4), 443-465.

Kayhan, T. (2005), Girişimcilik İklimi ve Yenilik Performansına Etkileri, (Yayınlanmamış Yüksek Lisans Tezi), Gebze Yüksek Teknoloji Enstitüsü, Sosyal Bilimler Enstitüsü, Gebze.

KİKTM, Karaman İl Kültür ve Turizm Müdürlüğü. (2021). Bakanlık ve Belediye Belgeli Oteller. [URL: https://karaman.ktb.gov.tr/] (Erişim Tarihi: 05 Şubat 2021).

Kinter, O. (2016). Örtük Liderlik Kuramı Çerçevesinde Güç Mesafesi ile Dönüşümcü ve Etkileşimci Liderlik İlişkisi, (Yayınlanmamış Yüksek Lisans Tezi), Balıkesir Üniversitesi, Sosyal Bilimler Enstitüsü, Balıkesir.

Kurt, T. (2010). Örgüt Kültürünün Yenilikçilik (İnovasyon) Performansı Üzerindeki Etkileri: Kayseri İmalat Sektöründe Uygulama, (Yayınlanmamış Yüksek Lisans Tezi), Erciyes Üniversitesi, Sosyal Bilimler Enstitüsü, Kayseri.

Laursen, K. ve Salter A. (2006). Open for innovation: The role of openness in explaining innovation performance among U.K. manufacturing firms. Strategic Management Journal, 27(2006), 131-150.

Lee, M. (2014). Transformational leadership: Is it time for a recall?, International Journal of Management and Applied Research, 1(1), 17-29.

Li, J. Xia, J. ve Zajac, E. (2017). On the duality of political and economic stakeholder influence on firm innovation performance: Theory and evidence from Chinese firms. Strategic Management Journal, 39, 193-216.

McMurray, A. J., Islam, M. M., Sarros, J. C. ve Pirola-Merlo, A. (2012). The impact of leadership on workgroup climate and performance in a non-profit organization. Leadership \& Organization Development Journal, 33(6), 522-549.

Oğuztürk, B. S. (2003). Yenilik kavramı ve teorik temelleri. Süleyman Demirel Üniversitesi İktisadi ve İdari Bilimler Fakültesi 8(2), 253-273.

Öğe, H. S. ve Canbolat, M. A. (2019). Farklılıkların yönetiminin örgütsel yaratıcılık ve yenilik performansı üzerine etkisi: Tekstil sektöründe bir uygulama. Yorum-Yönetim-Yöntem Uluslararası Yönetim-Ekonomi ve Felsefe Dergisi, 7(2), 111-128.

Özbağ, G. K. (2010). Temel Yetenek Tabanlı Yönetim Modelinin Yenilik Performansına Etkileri Üzerine Bir Araştırma, (Yayınlanmamış Doktora Tezi), Kocaeli Üniversitesi, Sosyal Bilimler Enstitüsü, Kocaeli. 
Özmen, M. (2015). Yöneticilerin Liderlik Tarzlarının Çalışanın İş Tatminine Etkisi ve Kocaeli Sanayi Bölgesinde Bir Uygulama, (Yayınlanmamış Yüksek Lisans Tezi), İstanbul Gelişim Üniversitesi, Sosyal Bilimler Enstitüsü, İstanbul.

Öztürk, D. G. (2019). Örgüt ikliminin yenilik performansı üzerine etkisi: Medikal sanayi sektöründe bir araştırma. Akademik Hassasiyetler, 6(12), 335-356.

Pradhan, S., Jena, L. K. ve Bhattacharyya, P. (2018). Transformational leadership and contextual performance: Role of integrity among Indian IT professionals. International Journal of Productivity and Performance Management, 67(2), 445-462.

Prajogo, D. I. ve Ahmed, P. K. (2006), Relationships between innovation stimulus, innovation capacity, and innovation performance. R\&D Management 36(5), 499-515.

Prajogo, D. I. ve Sohal, A. S. (2003). The relationship between TQM practices, quality performance, and innovation performance: An empirical examination. International Journal of Quality \& Reliability Management, 20(8), 901-918.

Prajogo, D. I. ve Sohal, A.S. (2004). The multidimensionality of TQM practices in determining quality and innovation performance - an empirical examination. Technovation, 443453.

Rajabi, K. M. (2020). Dönüşümcü ve Etkileşimci Lider Davranışlarının Örgüt Kültürüne Etkisi ve Buna Yönelik Bir Araştırma, (Yayınlanmamış Yüksek Lisans Tezi), İstanbul Aydın Üniversitesi, Lisansüstü Eğitim Enstitüsü, İstanbul.

Samur, S. B. (2011). The Mediating Role of Innovative Work Behaviors Between Intrapreneurial Climate and Organizational Innovativeness: An Empiricial Study, (Unpublished Master's Thesis), Yasar University, Graduate School of Social Sciences, İzmir.

Si, S. ve Wei, F. (2012). Transformational and transactional leaderships, empowerment climate, and innovation performance: A multilevel analysis in the Chinese context. European Journal of Work and Organizational Psychology, 21(2), 299-320.

Sobacı, F. (2014). Banka Yöneticilerinin Dönüşümcü ve Etkileşimci Liderlik Tarzları ile Çatışma Yönetim Stratejileri: Türkiye Genelinde Bir Uygulama, (Yayınlanmamış Yüksek Lisans Tezi), Gaziosmanpaşa Üniversitesi, Sosyal Bilimler Enstitüsü, Tokat.

Temel, E. (2016). Dönüşümcü Liderlik ve Psikolojik Güçlendirme Arasındaki İlişkide Örgütsel Özdeşleşenin Aracılık Rolü: Nazilli' deki Kamu Kurumlarında Bir Uygulama, (Yayınlanmamış Yüksek Lisans Tezi), Adnan Menderes Üniversitesi, Sosyal Bilimler Enstitüsü, Aydın.

Tokmak, M. (2019). Dönüştürücü ve etkileşimci liderlik tarzı ile negatif inovasyon algısı arasındaki ilişkiye yönelik bir araştırma. Kahramanmaraş Sütçü İmam Üniversitesi Sosyal Bilimler Dergisi, 17(1), 441-464.

Umair, A., Abbas, S. S., Asif, Q. M. Hussain, S. M. ve Muhammad, K. F. (2018). Nurturing innovation performance through corporate entrepreneurship: The moderation of employee engagement. Studies in Business and Economics, 13(2), 20-30.

Wang, X. H., Kim, T. Y. ve Lee D. R. (2016). Cognitive diversity and team creativity: Effects of team intrinsic motivation and transformational leadership. Journal of Business Research, 69(2016), 3231-3239. 
Whittington J. L. Goodwin, V. L. ve Murray, B. (2004). Transformational leadership, goal difficulty, and job design: Independent and interactive effects on employee outcomes. The Leadership Quarterly, 15(2004), 593-606.

Yaşlığlu, M. M. (2017). Sosyal bilimlerde faktör analizi ve geçerlilik: keşfedici ve doğrulayıcı faktör analizlerinin kullanılması. İstanbul Üniversitesi İşletme Fakültesi Dergisi, 46(Özel Say1), 74-85.

Yavuz Ç. (2010). İşletmelerde inovasyon-performans ilişkisinin incelenmesine dönük bir çalışma. Girişimcilik ve Kalkınma Dergisi, 5(2), 143-173.

Yavuz, E. (2008). Dönüşümcü ve Etkileşimci Liderlik Davranışının Örgütsel Bağl1lığa Etkisinin Analizi, (Yayınlanmamış Doktora Tezi), Gazi Üniversitesi, Eğitim Bilimleri Enstitüsü, Ankara.

Yücel, E. ve Özgül, E. (2020). İşletmelerin yenilik performansının arttırılmasında üniversitesanayi işbirliğinin rolü. Ekonomi, Politika \& Finans Araştırmaları Dergisi, 5(2), 404-434.

Zehir, C. ve Özşahin, M. (2008). A field research on the relationship between strategic decisionmaking speed and innovation performance in the case of Turkish large-scale firms. Management Decision, 46(5), 709-724.

Zeng, S. X., Xie, X. M. ve Tam, C. M. (2010). Relationship between cooperation networks and innovation performance of SMEs. Technovation 30(2010), 181-194.

Zhu, W., Sosik, J. J., Riggio, R. E. ve Yang, B. (1992). Relationships between transformational and transactional leadership and followers' organizational identification: The role of psychological empowerment. Institute of Behavioral and Applied Management, 13, 186-212. 